\title{
Characteristics of Xanthomonas cucurbitae Isolates from Pumpkins and Survival of the Bacterium in Pumpkin Seeds
}

\author{
X. Zhang and M. Babadoost, ${ }^{\dagger}$ Department of Crop Sciences, University of Illinois, Urbana 61801
}

\begin{abstract}
This study was conducted to determine characteristics of Xanthomonas cucurbitae, the causal agent of bacterial spot of pumpkin, and survival of the bacterium in pumpkin seeds. Fourteen $X$. cucurbitae isolates from the north central region of the United States, along with the $X$. cucurbitae strain 23378 from the American Type Culture Collection, were included in this study. The range of minimum, optimum, and maximum temperatures for colony development of $X$. cucurbitae were 4 to $6^{\circ} \mathrm{C}, 24$ to $30^{\circ} \mathrm{C}$, and 34 to $36^{\circ} \mathrm{C}$, respectively. Optimum $\mathrm{pH}$ for colony development ranged from 6.5 to 8.0. Leaves of 3-week-old pumpkins 'Howden' and 'Dickinson' were inoculated with $X$. cucurbitae isolates $\left(10^{8} \mathrm{CFU} / \mathrm{ml}\right)$.

There was a significant difference in the postinoculation periods for appearance of bacterial lesions on the leaves among the isolates; however, there was no significant difference in diameters of the lesions on each of the pumpkin cultivar 7 days after inoculation. Four of the isolates caused significantly larger lesions on 'Dickinson' leaves than 'Howden' leaves. Naturally infected 'Howden' pumpkin and inoculated 'Dickinson' pumpkin seeds with $X$. cucurbitae were stored at 4 and $22^{\circ} \mathrm{C}$. X. cucurbitae was isolated from both naturally infected and inoculated seeds 24 months after storage at both 4 and $22^{\circ} \mathrm{C}$, and the isolated bacteria were pathogenic.
\end{abstract}

Bacterial spot of pumpkin, caused by Xanthomonas cucurbitae (ex Bryan) Vauterin et al. (syn. Xanthomonas campestris [Pammel] Dowson pv. cucurbitae [Bryan] Dye) was first reported as bacterial leaf spot on 'Hubbard' squash in New York in 1926 (Bryan 1930). In the past 10 years, the disease has become one of the most important threats to production of pumpkins (Cucurbita pepo L. and Cucurbita moschata [Duchesne] Duchesne ex Poir) in Illinois, in other pumpkin growing areas in the United States, and in some pumpkin productions throughout the world (Babadoost et al. 2012; Babadoost and Zitter 2009; Egel et al. 2017; Lamichhane et al. 2010; Pruvost et al. 2008; Ravanlou and Babadoost 2015). The disease causes up to $100 \%$ yield losses in pumpkin fields (Babadoost and Ravanlou 2012; Liu et al. 2016; Ravanlou and Babadoost 2015).

$X$. cucurbitae infects leaves and fruits of pumpkins (Ravanlou and Babadoost 2015; Williams and Zitter 1996). Major symptoms on leaves are small, round to angular, beige lesions surrounded by a yellow halo (Ravanlou and Babadoost 2015; Williams and Zitter 1996). Lesions may coalesce to cover large parts of the leaves as the disease progresses. However, on certain pumpkin cultivars, the lesions may appear more angular, similar to the lesions from angular leaf spot, caused by Pseudomonas lachrymans (Kado 2010; Ravanlou and Babadoost 2015). Fruit symptoms include lesions that are small (1 to $3 \mathrm{~mm}$ in diameter), circular, and slightly sunken with a beige center and brown halo (Liu et al. 2016; Ravanlou and Babadoost 2015; Williams and Zitter 1996). In the late stages of fruit development, the lesions may reach 10 to $15 \mathrm{~mm}$ in diameter. Infected fruit may be colonized by secondary fungi and bacteria, causing rapid decay of fruits (Babadoost and Zitter 2009; Liu et al. 2016). X. cucurbitae also infects other cucurbits, especially winter squash, causing similar symptoms described for pumpkins (Bineeta et al. 1999; Liu et al. 2016; Pruvost et al. 2009; Williams and Zitter 1996).

$X$. cucurbitae has been reported as a seedborne pathogen (Williams and Zitter 1996). Infected seed may play an important role in dispersal of the pathogen, especially over long distances. Although $X$. cucurbitae has been isolated from pumpkin seeds (Ravanlou

${ }^{\dagger}$ Corresponding author: M. Babadoost; E-mail: babadoos@illinois.edu

Funding: This research was supported in part by funds from NCR-SARE grant (project no. GNC15-217).

Accepted for publication 10 March 2018.

(C) 2018 The American Phytopathological Society and Babadoost 2015; Williams and Zitter 1996), there is no information on the survival of the pathogen in seeds of pumpkins or other cucurbits. The objectives of this research were to: (i) study characteristics of $X$. cucurbitae isolates from the north central region (NCR) of the U.S., and (ii) determine survival of $X$. cucurbitae in pumpkin seeds.

\section{Materials and Methods}

Bacterial isolates. Fifteen isolates of $X$. cucurbitae were used in this study (Table 1). American Type Culture Collection strain 23378 (ATCC-23378) was used as a positive control and the other 14 isolates were collected from pumpkin fruits in Illinois, Indiana, Iowa, Kansas, Michigan, Ohio, and Wisconsin in the NCR. All $X$. cucurbitae isolates used in this study were stored in $30 \%$ glycerol at $-80^{\circ} \mathrm{C}$.

Effects of temperature on colony development. All 15 isolates of $X$. cucurbitae, described above, were tested on three culture media, including yeast-extract-dextrose-calcium-carbonate agar (YDC), Luria Bertani agar (LB), and nutrient agar (NA) in Petri plates to determine their colony development at different temperatures. To prepare the test plates, first $X$. cucurbitae isolates were cultured on LB agar and incubated at $24 \pm 1{ }^{\circ} \mathrm{C}$ for $48 \mathrm{~h}$. Then, a cell suspension of each isolate was prepared separately by washing bacterial colonies from the Petri plates with sterile distilled water (SDW) into a $15 \mathrm{ml}$ conical tube. The cell density of each isolate was adjusted to $10^{8} \mathrm{CFU} / \mathrm{ml}$ with the use of a spectrophotometer (Smart Spec 3000; Bio-Rad, Philadelphia, $\mathrm{PA})$ at $\mathrm{OD}_{600}(\mathrm{OD}=0.5$ at $600 \mathrm{~nm})$. One loopful of each bacterial suspension was streaked onto each of YDC, LB, and NA in Petri plates and the plates were incubated at each of the test temperatures, including $3,4,5,6,7,20,21,22,23$, $24,25,26,27,28,29,30,31,32,33,34,35,36,37,38,39$, and $40^{\circ} \mathrm{C}$ for 10 days. Each of the $X$. cucurbitae isolate at each temperature was cultured in four Petri plates with YDC, LB, or NA. Development of bacterial colonies was recorded daily. After 10 days, a scale of 0 to 4 was used to rate the mass of colonies formed, in which $0=$ no colony developed; $1=$ one quarter, $2=$ half, $3=$ three quarters, and $4=$ all of the streaked lines in the plate were covered with the bacterial colonies. This study was designed to determine the minimum, maximum, and optimum temperatures for colony development of the X. cucurbitae isolates. The experiment was repeated once.

Effects of pH on colony development. Cell suspension of the $X$. cucurbitae isolates were prepared as described previously. LB and NA media with $\mathrm{pH}$ adjusted to $4.5,5.0,5.5,6.0,6.5,7.0,7.5,8.0$, $8.5,9.0,9.5$, and 10.0 were used (Table 2). X. cucurbitae isolates 
were grown on LB agar and cell densities of the suspensions of the isolates were adjusted to $10^{8} \mathrm{CFU} / \mathrm{ml}$, as described in the previous experiment. A loopful of bacterial suspension from each isolate was streaked onto each of the culture media in Petri plate. Five streak lines were made in each plate. The lines were straight, one edge of the plate to another edge, and equally distanced from each other. Four culture plates for each isolate $\times \mathrm{pH}$ were used. The plates were incubated at $24 \pm 1{ }^{\circ} \mathrm{C}$ in the dark for $72 \mathrm{~h}$, and colony development was recorded. A scale of 0 to 4 was used to rate the mass of colony formation, as described in the previous experiment. The experiment was repeated once.

Pathogenicity of $X$. cucurbitae isolates. Fourteen $X$. cucurbitae isolates from the NCR were tested to assess pathogenic variation among the isolates. The ATCC-23378 and SDW were used as positive and negative controls, respectively. Pumpkins Cucurbita pepo 'Howden' and Cucurbita moschata 'Dickinson' were used in this study. Pumpkin seeds were sown in 32-cell plastic trays filled with a mixture of soil/peat/perlite (1:2:1), and grown in a greenhouse at 24 to $28^{\circ} \mathrm{C}$ for 3 weeks. Plants were then inoculated with $X$. cucurbitae suspension.

A modified syringe infiltration method developed by previous investigators (Barak et al. 2001; Katagiri et al. 2002) was used to inoculate plants with the $X$. cucurbitae isolates. For each isolate, four plants from each cultivar, and the first two true leaves of each plant, were inoculated. On each leaf, three infiltrations of inoculum $(300 \mu \mathrm{l}$ of inoculum per infiltration) were made using a 10-ml syringe. Hours post inoculation (hpi) for the appearance of bacterial lesions was recorded every $12 \mathrm{~h}$ from the time of inoculation. Lesion diameters were measured $168 \mathrm{~h}$ (7 days) after inoculation.

Seven days post inoculation (dpi), all symptomatic leaves were collected to reisolate $X$. cucurbitae from the lesions. Leaf samples were soaked in $75 \%$ ethanol for $3 \mathrm{~min}$ and then rinsed three times with SDW. Leaf tissues with lesions were cut in pieces of approximately $5 \mathrm{~mm}$ in diameter. One piece from each leaf with a single lesion was placed onto the kasugamycin-cephalexin (KC) agar. KC agar medium contained $7 \mathrm{~g}$ yeast extract, $7 \mathrm{~g}$ peptone, $7 \mathrm{~g}$ glucose, $18 \mathrm{~g}$ agar, $20 \mathrm{mg}$ propiconazol, $40 \mathrm{mg}$ cephalexin, and $20 \mathrm{mg}$ kasugamycin in $1,000 \mathrm{ml}$ distilled water. In addition, two pieces from each leaf with lesions were transferred into a microcentrifuge tube with $1 \mathrm{ml}$ of SDW. The tube was vortexed for $30 \mathrm{~s}$ to release bacterial cells from plant tissue into water. For each sample, a loopful of bacterial suspension was streaked onto $\mathrm{KC}$ medium in a $100-\mathrm{mm}$ Petri plate. All plates were incubated at $24 \pm 1{ }^{\circ} \mathrm{C}$ for $48 \mathrm{~h}$ in darkness. Xanthomonas-like colonies were subcultured onto YDC for morphological identification (Liu et al. 2016; Ravanlou and Babadoost 2015) and tested by PCR (Zhao et al. 2002) using primers RST2/RST3 (Ravanlou and Babadoost 2015; Schaad et al. 2001) for molecular identification.

Survival of $X$. cucurbitae in pumpkin seeds. Seeds of pumpkin 'Howden' and 'Dickinson' were used in this study. 'Howden' seeds were collected in November 2013 from either symptomatic or asymptomatic fruits produced at the University of Illinois Vegetable Research Farm, Champaign, IL. Pumpkin fruits with $2 \%$ or greater of the surface covered with bacterial lesions were cut open and seeds were collected. These seeds were considered as naturally infected seeds with $X$. cucurbitae. Seeds collected from asymptomatic pumpkin fruit were considered as uninfected (control) seeds (Table 3). Seeds of 'Dickinson' pumpkin were obtained from Libby's Processing Company in Morton, IL. Samples of seeds collected from both symptomatic and asymptomatic fruits of 'Howden' pumpkin and seeds of 'Dickinson' pumpkin were tested for the presence of $X$. cucurbitae according to the method developed by Ravanlou and

Table 2. Colony development of 15 isolates of Xanthomonas cucurbitae from the north central region on nutrient agar (NA) and Luria Bertani agar (LB) media with different $\mathrm{pH}$ levels

\begin{tabular}{lll}
\hline & \multicolumn{2}{c}{$\begin{array}{c}\text { Intensity of bacterial colonies } \\
\text { on culture media }^{\mathbf{y}}\end{array}$} \\
\cline { 2 - 3 } $\mathbf{p H}^{\mathbf{x}}$ & $\mathbf{N A}$ & $\mathbf{L B}$ \\
\hline 4.5 & $0.00 \mathrm{~d}^{\mathrm{z}}$ & $0.00 \mathrm{~g}$ \\
5.0 & $0.67 \mathrm{~cd}$ & $0.50 \mathrm{~g}$ \\
5.5 & $2.00 \mathrm{~b}$ & $2.00 \mathrm{~d}$ \\
6.0 & $3.33 \mathrm{a}$ & $3.50 \mathrm{abc}$ \\
6.5 & $4.00 \mathrm{a}$ & $4.00 \mathrm{a}$ \\
7.0 & $4.00 \mathrm{a}$ & $4.00 \mathrm{a}$ \\
7.5 & $3.67 \mathrm{a}$ & $3.83 \mathrm{ab}$ \\
8.0 & $3.67 \mathrm{a}$ & $3.67 \mathrm{abc}$ \\
8.5 & $3.33 \mathrm{a}$ & $3.33 \mathrm{c}$ \\
9.0 & $1.33 \mathrm{bc}$ & $1.33 \mathrm{e}$ \\
9.5 & $1.33 \mathrm{bc}$ & $0.00 \mathrm{~g}$ \\
10.0 & $1.33 \mathrm{bc}$ & $0.00 \mathrm{~g}$ \\
\hline
\end{tabular}

${ }^{\mathrm{x}} \mathrm{pH}$ of the culture medium was adjusted by adding $\mathrm{NaOH}$ or $\mathrm{HCl}$ to culture media. Data from 14 isolates tested were combined together before analysis. ${ }^{y}$ Intensity of colony development was rated using a 0 to 4 scale, where $0=$ no colony developed; and $1=$ a quarter, $2=$ half, $3=$ three quarters, and $4=$ all of the streaked lines were covered with the bacterial colonies.

${ }^{\mathrm{z}}$ In each column, values with a letter in common are not significantly different from each other according to Tukey's honest significant difference $(\alpha=0.05)$.

Table 1. Minimum, maximum, and optimum temperatures for colony development of Xanthomonas cucurbitae on yeast-extract-dextrose-calcium-carbonate agar medium (YDC), Luria Bertani agar medium (LB), and nutrient agar medium (NA)

\begin{tabular}{|c|c|c|c|c|c|c|c|c|c|c|c|c|}
\hline \multirow[b]{2}{*}{ Isolate } & \multicolumn{4}{|c|}{ Minimum temperature $\left({ }^{\circ} \mathrm{C}\right)$} & \multicolumn{4}{|c|}{ Maximum temperature $\left({ }^{\circ} \mathrm{C}\right)$} & \multicolumn{4}{|c|}{ Optimum temperature $\left({ }^{\circ} \mathrm{C}\right)$} \\
\hline & YDC & LB & NA & LSD $^{\mathbf{y}}$ & YDC & LB & NA & LSD & YDC & LB & NA & LSD \\
\hline ATCC-23378 & 6 & 6 & 6 & $\mathrm{NS}^{\mathrm{z}}$ & 34 & 35 & 34 & NS & $24-29$ & $24-29$ & 24-29 & NS \\
\hline IA382 & 5 & 5 & 5 & NS & 35 & 35 & 34 & NS & $24-29$ & $24-29$ & 24-29 & NS \\
\hline IA389 & 5 & 5 & 5 & NS & 34 & 35 & 34 & NS & $24-29$ & $24-30$ & 24-29 & NS \\
\hline IL232 & 5 & 5 & 5 & NS & 34 & 35 & 35 & NS & $24-29$ & $24-30$ & 24-29 & NS \\
\hline IL234 & 5 & 5 & 5 & NS & 35 & 35 & 35 & NS & $24-30$ & $24-30$ & 24-30 & NS \\
\hline IN332 & 6 & 4 & 5 & NS & 35 & 36 & 35 & NS & $24-30$ & 24-29 & 24-30 & NS \\
\hline IN334 & 5 & 4 & 5 & NS & 35 & 36 & 35 & NS & $24-29$ & $24-29$ & 24-29 & NS \\
\hline KS455 & 6 & 5 & 5 & NS & 35 & 35 & 34 & NS & $24-29$ & $24-30$ & 24-29 & NS \\
\hline KS456 & 6 & 5 & 5 & NS & 34 & 35 & 35 & NS & $24-29$ & $24-29$ & 24-30 & NS \\
\hline MI358 & 5 & 4 & 6 & NS & 35 & 36 & 35 & NS & $24-29$ & $24-29$ & 24-29 & NS \\
\hline MI359 & 6 & 6 & 5 & NS & 34 & 35 & 34 & NS & $24-29$ & $24-29$ & 24-29 & NS \\
\hline $\mathrm{OH} 256$ & 6 & 6 & 6 & NS & 35 & 35 & 35 & NS & $24-30$ & $24-30$ & 24-30 & NS \\
\hline $\mathrm{OH} 261$ & 6 & 6 & 6 & NS & 35 & 35 & 35 & NS & $24-30$ & $24-30$ & $24-29$ & NS \\
\hline WI205 & 5 & 5 & 5 & NS & 35 & 34 & 35 & NS & $24-30$ & $24-30$ & $24-30$ & NS \\
\hline WI206 & 6 & 5 & 5 & NS & 35 & 34 & 34 & NS & $24-29$ & $24-29$ & 24-29 & NS \\
\hline LSD & NS & NS & NS & - & NS & NS & NS & - & NS & NS & NS & - \\
\hline
\end{tabular}

${ }^{\mathrm{y}} \mathrm{LSD}=$ Least significant difference.

${ }^{\mathrm{z}} \mathrm{NS}=$ not significant at $P=0.05$ 
Babadoost (2015). Uninfected seeds of 'Dickinson' pumpkin were inoculated with each of three isolates of $X$. cucurbitae, including IL232, OH261, and ATCC-23378, and considered as inoculated seeds (Table 3). Thus, naturally infected 'Howden' seeds, inoculated 'Dickinson' seeds, and X. cucurbitae-free 'Howden' and 'Dickinson' seeds were used in this study.

A modified method developed by Carisse et al. (2000) was used to inoculate seeds with $X$. cucurbitae. Seeds were either inoculated without surface disinfestation or after surface disinfestation. Seeds were surface disinfested by soaking them in $1 \% \mathrm{NaClO}(2 \mathrm{ml}$ $\mathrm{NaClO} / \mathrm{g}$ of seed for $3 \mathrm{~min}$ ), followed by three rinses with SDW (4 ml SDW/g of seed), each time for $1 \mathrm{~min}$. After the surface disinfestation, seeds were dried on sterile blotter paper in a laminar flow hood (The Baker Inc., Sanford, ME). Seeds were inoculated for either 6 or 20 min by soaking them in X. cucurbitae suspension $\left(10^{8} \mathrm{CFU} / \mathrm{ml}\right)$ prepared from 48 -h-old cultures of each of the isolates mentioned above. Inoculated seeds were dried in the laminar flow hood and stored at $4{ }^{\circ} \mathrm{C}$ until they were used. Four replications of each of the 16 treatments (Table 3 ) of naturally infected, inoculated, and uninoculated seeds were stored at 4 and $22^{\circ} \mathrm{C}$.

Samples of naturally infected seeds of pumpkin 'Howden,' stored at $4{ }^{\circ} \mathrm{C}$, were tested for the presence of $X$. cucurbitae after $8,11,14,17,20,23,26$, and 29 months. All other treated and control seeds were tested for the presence of $X$. cucurbitae after 3, 6, 9, $12,15,18,21$, and 24 months in storage. A sample of 150 seeds from each replication of each treatment from each storage was tested. Each sample was placed in a sterile flask with $100 \mathrm{ml}$ of washing saline solution (WSS). WSS was prepared by adding $7.5 \mathrm{~g}$ of $\mathrm{NaCl}$ and $200 \mu \mathrm{l}$ of Tween-20 to $1,000 \mathrm{ml}$ distilled water and then sterilized in an autoclave at $121^{\circ} \mathrm{C}$ for $20 \mathrm{~min}$. Flasks with seeds in the sterilized WSS were shaken on a rotary shaker (Fisher Scientific Co., Clinical Rotator 14-251-200) at $120 \mathrm{rpm}$ at $4^{\circ} \mathrm{C}$ in the dark for $12 \mathrm{~h}$. The seed wash was filtered through four layers of sterile cheesecloth and rinsed with $30 \mathrm{ml}$ of SDW. Collected seed wash was centrifuged at $14,000 \times g$ for $7 \mathrm{~min}$. Supernatant was discarded and the pellet was resuspended in the PBS buffer. The PBS buffer was prepared by dissolving $3.9 \mathrm{~g} \mathrm{KH}_{2} \mathrm{PO}_{4}, 2 \mathrm{~g} \mathrm{KCl}, 80 \mathrm{~g}$ $\mathrm{NaCl}$, and $17.9 \mathrm{~g} \mathrm{Na}_{2} \mathrm{HPO}_{4}$ in $1,000 \mathrm{ml} \mathrm{SDW}$ with $\mathrm{pH}$ 7.4. Dilutions of $10^{-1}, 10^{-2}, 10^{-3}, 10^{-4}, 10^{-5}$, and $10^{-6}$ were prepared from the seed wash in PBS buffer and $100 \mu$ of each dilution was spread onto KC agar. Petri plates were incubated at $24 \pm 1^{\circ} \mathrm{C}$ for 4 days. Xanthomonas-like colonies were counted and subcultured onto
YDC for morphological characteristics of the colonies, PCR tested using RST2/RST3 primers for molecular identification of the pathogen, and inoculated to leaves of 'Howden' pumpkin in the greenhouse for pathogenicity testing.

Data analysis. The data were analyzed using SAS 9.4 (SAS Institute Inc. Cary, NC). To analyze the data of the effects of temperature and $\mathrm{pH}$ on colony development and pathogenicity experiments, normality of the data were tested using PROC UNIVARIATE procedure, and homogeneity of tests were examined with the BERLETT test. Least significant difference at $\alpha=0.05$ was used for mean separation test.

For the $X$. cucurbitae survival in pumpkin seeds, the data of colony forming units (CFU) were natural-log transformed to meet the assumption of normality and homogeneity before conducting analysis of variance (ANOVA). The PROC GLM procedure was used to determine the effects of three fixed factors (storage temperature, seed treatment, and seed-inoculation time period) at $\alpha=0.05$. The Tukey honest significant difference test was used to compare differences among the number of CFUs from different samples over time. Type I error was controlled at $\alpha=0.05$. Regression analysis were conducted in Excel to predict $X$. cucurbitae survival in seeds at different temperatures. For naturally infected and inoculated seeds, equations $\hat{\mathrm{Y}}=\mathrm{a}+\mathrm{bx}+\mathrm{cx}^{2}$ and $\hat{\mathrm{Y}}=\mathrm{a}+\mathrm{bx}$, respectively, were used, in which $\hat{\mathrm{Y}}=$ predicted $\log _{\mathrm{e}}$ number of recovered $\mathrm{CFU}, \mathrm{a}=$ number of recovered $\mathrm{CFU}$ of the original sample prior to placing in the storage, $\mathrm{b}=$ rate of decline of number of recovered CFU over the time, and $\mathrm{x}=$ time (month).

\section{Results}

Effects of temperature on colony development. The range of minimum, maximum, and optimum temperatures for colony development of $X$. cucurbitae isolates were 4 to $6^{\circ} \mathrm{C}, 34$ to $36^{\circ} \mathrm{C}$, and 24 to $30^{\circ} \mathrm{C}$, respectively (Table 1 ). There were no significant differences for minimum, maximum, and optimum temperatures for colony development among the isolates. Culture medium did not significantly affect colony development of $X$. cucurbitae.

Effects of pH on colony development. There was no significant difference on colony development among tested isolates of $X$. cucurbitae, so combined data from the isolates are presented (Table 2). The most favorable $\mathrm{pH}$ for colony development of the isolates on both NA and LB media were 6.5 and 7. There was no significant difference on colony development among $\mathrm{pH} 6.0,6.5,7.0,7.5,8.0$, and

Table 3. Inoculation of pumpkin seeds with Xanthomonas cucurbitae

\begin{tabular}{|c|c|c|c|c|}
\hline \multirow[b]{2}{*}{ Treatments $^{\mathrm{w}}$} & \multicolumn{2}{|c|}{ Seed inoculation } & \multirow[b]{2}{*}{ Seed surface disinfestation ${ }^{\mathrm{z}}$} & \multirow[b]{2}{*}{ Pumpkin cultivar } \\
\hline & Bacterial isolate $^{\mathrm{x}}$ & Inoculation time $(\min )^{y}$ & & \\
\hline Uninoculated-1 (control) & - & - & - & Howden \\
\hline Uninoculated-2 (control) & - & - & + & Dickinson \\
\hline Uninoculated-3 (control) & - & - & - & Dickinson \\
\hline Naturally infected-1 & - & - & - & Howden \\
\hline Artificially Inoc-1 & ATCC-23378 & 6 & + & Dickinson \\
\hline Artificially Inoc-2 & ATCC-23378 & 20 & + & Dickinson \\
\hline Artificially Inoc-3 & ATCC-23378 & 6 & - & Dickinson \\
\hline Artificially Inoc-4 & ATCC-23378 & 20 & - & Dickinson \\
\hline Artificially Inoc-5 & IL232 & 6 & + & Dickinson \\
\hline Artificially Inoc-6 & IL232 & 20 & + & Dickinson \\
\hline Artificially Inoc-7 & IL232 & 6 & - & Dickinson \\
\hline Artificially Inoc-8 & IL232 & 20 & - & Dickinson \\
\hline Artificially Inoc- 9 & OH261 & 6 & + & Dickinson \\
\hline Artificially Inoc-10 & $\mathrm{OH} 261$ & 20 & + & Dickinson \\
\hline Artificially Inoc-11 & OH261 & 6 & - & Dickinson \\
\hline Artificially Inoc-12 & OH261 & 20 & - & Dickinson \\
\hline
\end{tabular}

${ }^{w}$ Naturally infected seeds were collected from fruit of the pumpkin cultivar Howden that were showing symptoms of bacterial spot. Artificially Inoc $=$ artificially inoculated seeds.

x ATCC-23378, IL232, and OH261 X. cucurbitae isolates were from the American Type Culture Collection, Illinois, and Ohio, respectively.

y Seeds were inoculated by soaking them in an X. cucurbitae suspension $\left(10^{8} \mathrm{CFU} / \mathrm{ml}\right)$ for either 6 or $20 \mathrm{~min}$.

$\mathrm{z}_{-}=$seeds were not surface disinfested; + = seeds were surface disinfested by soaking them in $0.6 \% \mathrm{NaClO}$ solution for 3 min, followed by three rinses with sterile distilled water. 
8.5 on NA; and among pH 6.0, 6.5, 7.0, 7.5, and 8.0 on LB. No colony developed on the culture media with $\mathrm{pH} 4.5$ on either NA or LB. Some colonies developed at $\mathrm{pH} 9.5$ and 10.0 on NA, but no colony developed at these $\mathrm{pH}$ levels on LB.

Pathogenicity of $X$. cucurbitae isolates. Bacterial lesions appeared on inoculated leaves of 'Howden' pumpkin 57 to 75 hpi and 'Dickinson' pumpkin 51 to 81 hpi (Table 4). Bacterial lesions developed significantly faster on leaves of both 'Howden' and
'Dickinson' pumpkins inoculated with isolate KS455 compared with most of the other isolates (Table 4). There were significant differences in the periods of time for initial appearance of leaf lesions between 'Howden' and 'Dickinson' plants inoculated with isolates KS455, KS456, OH256, and WI206 (Table 3). Similarly, there were significant differences in lesion diameters on 'Howden' pumpkin leaves compared to 'Dickinson' pumpkin inoculated with isolates MI358, OH256, OH261, and WI206 at 7 dpi (Table 4).

Table 4. Development of lesions on leaves of 'Howden' and 'Dickinson' pumpkins inoculated with isolates of Xanthomonas cucurbitae collected from pumpkin fields in the north central region ${ }^{\mathrm{v}}$

\begin{tabular}{|c|c|c|c|c|c|c|c|}
\hline \multirow[b]{2}{*}{ Isolate } & \multirow[b]{2}{*}{ Origin of the isolate } & \multicolumn{3}{|c|}{ Appearance of visible lesion on leaves (hpi ${ }^{w}$ ) } & \multicolumn{3}{|c|}{ Diameter of lesion 7 days post inoculation } \\
\hline & & Howden & Dickinson & $P$ value & Howden & Dickinson & $P$ value \\
\hline ATCC-23378 & - $^{\mathrm{x}}$ & $66 a b^{y}$ & $66 a b$ & NS & $5.08 \mathrm{a}$ & $5.00 \mathrm{a}$ & NS \\
\hline IA382 & Iowa & $72 \mathrm{a}$ & $72 \mathrm{a}$ & NS & $5.79 \mathrm{a}$ & $6.46 \mathrm{a}$ & NS \\
\hline IA389 & Iowa & $69 \mathrm{a}$ & $66 \mathrm{ab}$ & NS & $5.66 \mathrm{a}$ & $5.96 \mathrm{a}$ & NS \\
\hline IL232 & Illinois & $69 \mathrm{a}$ & $72 \mathrm{a}$ & NS & $5.91 \mathrm{a}$ & $5.92 \mathrm{a}$ & NS \\
\hline IL234 & Illinois & $72 \mathrm{a}$ & $72 \mathrm{a}$ & NS & $5.58 \mathrm{a}$ & $6.04 \mathrm{a}$ & NS \\
\hline IN332 & Indiana & $72 \mathrm{a}$ & $75 \mathrm{a}$ & NS & $6.41 \mathrm{a}$ & $5.83 \mathrm{a}$ & NS \\
\hline IN334 & Indiana & $72 \mathrm{a}$ & $75 \mathrm{a}$ & NS & $5.79 \mathrm{a}$ & $5.40 \mathrm{a}$ & NS \\
\hline KS455 & Kansas & $57 \mathrm{~b}$ & $51 \mathrm{~b}$ & 0.0128 & $5.56 \mathrm{a}$ & $5.00 \mathrm{a}$ & NS \\
\hline KS456 & Kansas & $75 \mathrm{a}$ & $71 \mathrm{a}$ & 0.0426 & $5.91 \mathrm{a}$ & $5.92 \mathrm{a}$ & NS \\
\hline MI358 & Michigan & $72 \mathrm{a}$ & $69 \mathrm{a}$ & NS & $5.33 \mathrm{a}$ & $6.46 \mathrm{a}$ & 0.0026 \\
\hline MI359 & Michigan & $69 \mathrm{a}$ & $66 a b$ & NS & $5.38 \mathrm{a}$ & $5.54 \mathrm{a}$ & NS \\
\hline $\mathrm{OH} 256$ & Ohio & $75 a$ & $81 \mathrm{a}$ & 0.0095 & $5.21 \mathrm{a}$ & $6.67 \mathrm{a}$ & $<0.0001$ \\
\hline OH261 & Ohio & $74 \mathrm{a}$ & $78 \mathrm{a}$ & NS & $5.29 \mathrm{a}$ & $6.33 \mathrm{a}$ & 0.0008 \\
\hline WI205 & Wisconsin & $72 \mathrm{a}$ & $75 \mathrm{a}$ & NS & $5.95 \mathrm{a}$ & $5.62 \mathrm{a}$ & NS \\
\hline WI206 & Wisconsin & $68 \mathrm{ab}$ & $75 a$ & 0.0063 & $6.00 \mathrm{a}$ & $7.46 \mathrm{a}$ & 0.0003 \\
\hline $\mathrm{SDW}^{\mathrm{z}}$ & - & - & - & - & - & - & - \\
\hline
\end{tabular}

v Two leaves of each plant and three spots on each leaf were inoculated. Inoculation of each leaf spot was by infiltration of $300 \mu l$ of bacterial suspensions $\left(10^{8} \mathrm{CFU} / \mathrm{ml}\right)$. Leaves of control plants were infiltrated with sterilized distilled water.

w Hours post inoculation.

x No symptom developed.

y Within each column, values with a letter in common are not significantly different from each other according to Tukey's honest significant difference test $(P=0.05)$.

${ }^{\mathrm{z}}$ Sterilized distilled water.

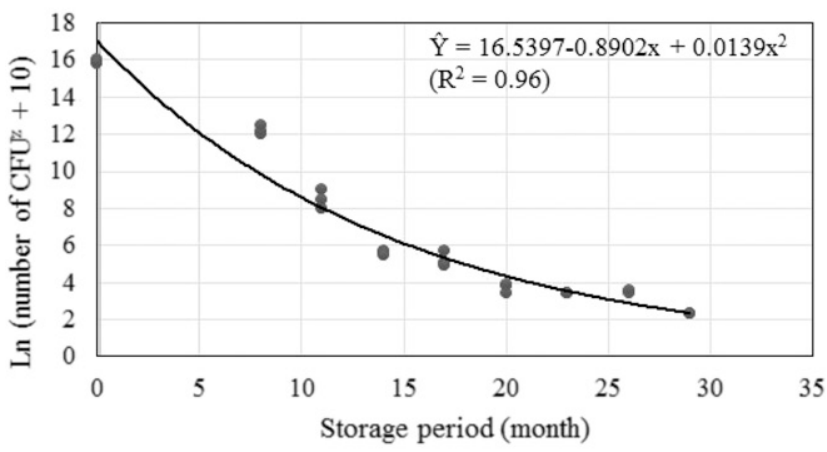

Naturally-infected seeds stored at $4^{\circ} \mathrm{C}$

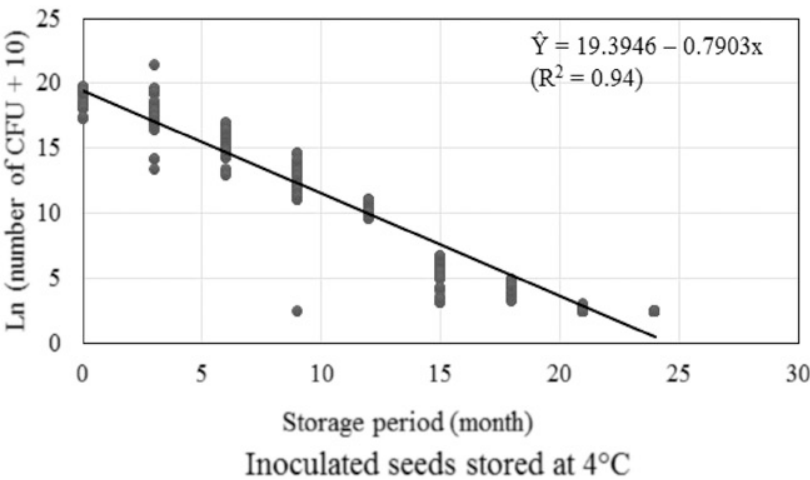

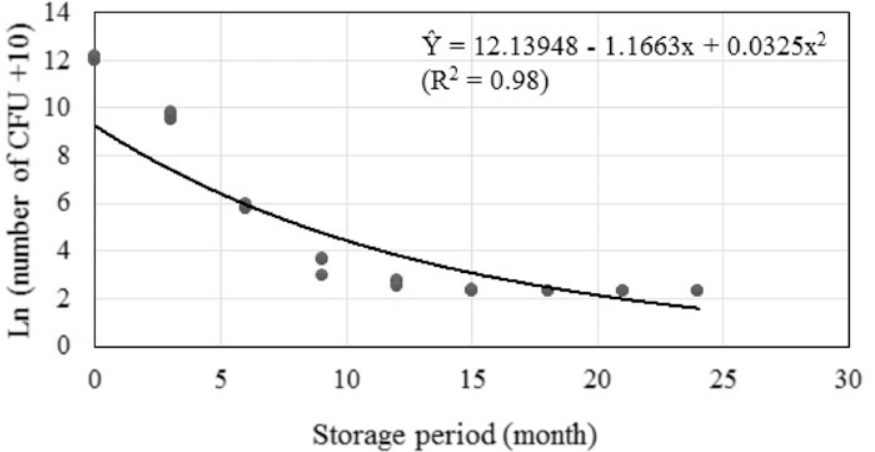

Naturally-infected seeds stored at $22^{\circ} \mathrm{C}$

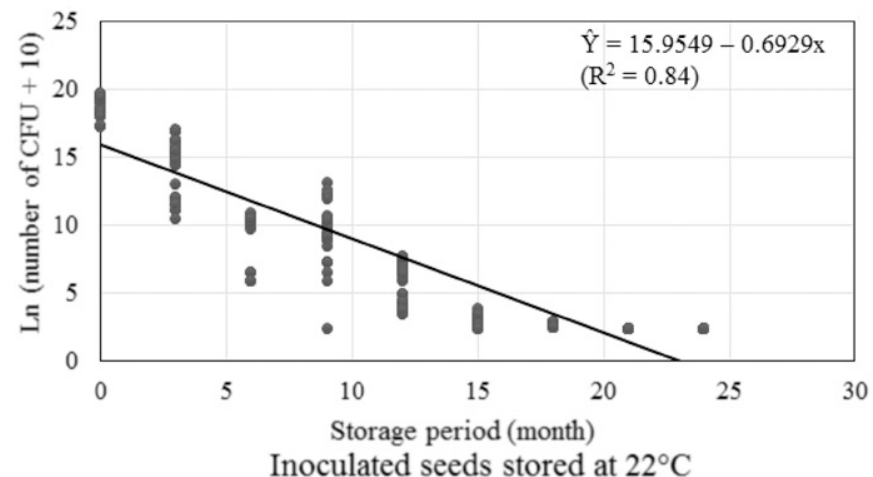

Fig. 1. Recovery of Xanthomonas cucurbitae from naturally infected and inoculated pumpkin seeds stored at 4 and $22^{\circ} \mathrm{C}$. Naturally infected seeds were stored at $4{ }^{\circ} \mathrm{C}$ for 29 months and all other seeds were stored for 24 months. $^{\mathrm{z}}=$ colony forming unit. 
However, there was no significant difference in diameter of leaf lesions caused by the $X$. cucurbitae isolates on either 'Howden' or 'Dickinson' pumpkins at 7 dpi (Table 4). X. cucurbitae was successfully isolated from all inoculated leaves and identified. All $X$. cucurbitae isolates used in this study produced mucoid, yellow colonies on YDC and $1.4 \mathrm{~kb}$ amplicons following the PCR test with RST2/RST3 primers. No symptom developed on leaves of plants infiltrated with SDW and no bacteria were isolated from infiltrated tissues.

Survival of $X$. cucurbitae in pumpkin seeds. Survival of $X$. cucurbitae were significantly affected by the storage temperature $(P=0.0039)$ and storage time $(P<0.0001)$. In the inoculated seeds, survival of $X$. cucurbitae was not significantly affected by $X$. cucurbitae isolate $(P=0.2133)$, seed inoculating time $(P=$ $0.7452)$, or seed surface disinfestation $(P=0.1980)$. Thus, data from all inoculated seeds at each storage condition were combined for analysis and presented together. X. cucurbitae was recovered from naturally infected seeds after 29 months at $4^{\circ} \mathrm{C}$ and $22^{\circ} \mathrm{C}$, and from inoculated seeds after 24 months at 4 and $22^{\circ} \mathrm{C}$ (Fig. 1). However, the number of $X$. cucurbitae CFUs recovered from seeds declined significantly over time at both storage temperatures. The relationships between the numbers of recovered $X$. cucurbitae CFUs and the time period (months) in naturally infected seeds at $4{ }^{\circ} \mathrm{C}$, naturally infected seeds at $22^{\circ} \mathrm{C}$, inoculated seeds at $4{ }^{\circ} \mathrm{C}$, and inoculated seeds at $22^{\circ} \mathrm{C}$ were $\hat{\mathrm{Y}}=16.5397-0.8902 \mathrm{x}+0.0139 \mathrm{x}^{2}$ $\left(\mathrm{R}^{2}=0.96\right), \hat{\mathrm{Y}}=12.13948-1.1663 \mathrm{x}+0.0325 \mathrm{x}^{2}\left(\mathrm{R}^{2}=0.98\right), \hat{\mathrm{Y}}=$ $19.3946-0.7903 x\left(R^{2}=0.94\right)$, and $\hat{Y}=15.9549-0.6929 x\left(R^{2}=\right.$ 0.84), respectively (Fig. 1). Colony morphology, results of PCR tests, and development of typical bacterial spots on inoculated pumpkin leaves showed that isolated bacteria from stored seeds were $X$. cucurbitae.

\section{Discussion}

All 15 isolates of $X$. cucurbitae used in this study produced yellow colonies on YDC, LB, and NA agar media; mucoid, convex colonies on YDC (Kado 2010; Rademaker et al. 2005; Ravanlou and Babadoost 2015); $1.4 \mathrm{~kb}$ amplicon following PCR with RST2/ RST3 primers (Ravanlou and Babadoost 2015; Schaad et al. 2001); and beige lesions with yellow halo on inoculated leaves of pumpkins 'Howden' and 'Dickinson' (Ravanlou and Babadoost 2015; Williams and Zitter 1996). Thus, all tested isolates belonged to the species of X. cucurbitae.

Bineeta et al. (1999) reported that $X$. cucurbitae cells did not multiply at temperatures above $35^{\circ} \mathrm{C}$, and optimal temperatures for colony development were 25 to $30^{\circ} \mathrm{C}$. Our studies showed similar results that $X$. cucurbitae cells do not multiply at temperatures above $36^{\circ} \mathrm{C}$ and below $4^{\circ} \mathrm{C}$, and optimum colony development at temperatures of 24 to $30^{\circ} \mathrm{C}$. All these findings indicate that $X$. cucurbitae multiply in a wide range of temperature and could infect pumpkin and other cucurbit plants at any growth stage as reported by Pruvost et al. (2009) and Babadoost and Ravanlou (2012).

We did not find any published reports on the effects of $\mathrm{pH}$ on colony development of $X$. cucurbitae. The results of our studies showed that cell colony development of $X$. cucurbitae was the optimum on both NA and LB media at pH 6.5 to 8.0; however, colonies of $X$. cucurbitae developed at $\mathrm{pH}$ levels ranging from 5 to 9 on both culture media. These results indicate that $X$. cucurbitae may infect plants at relatively wide ranges of acidic and alkaline conditions.

Limited information is available on the aggressiveness of $X$. cucurbitae on cucurbits. Ravanlou and Babadoost (2015) reported significant differences in the time period for the appearance of visible lesions in inoculated leaves of pumpkin 'Howden' among $X$. cucurbitae isolates collected from Illinois. Our studies also showed that the periods for initial appearance of visible symptoms in inoculated leaves of pumpkins 'Howden' and 'Dickinson' with 14 isolates collected from seven states in the NCR were significantly different. However, at $7 \mathrm{dpi}$, there was no significant difference in diameter of the lesions among the isolates on either 'Howden' or 'Dickinson' pumpkin. Further studies on other cucurbit species may show significant differences in aggressiveness among $X$. cucurbitae isolates.

Survival of some Xanthomonas species in seeds has been studied, but there is no published report on survival of $X$. cucurbitae in seeds. Survival of $X$. campestris. pv. vesicatoria in pepper seeds (Bashan et al. 1982), X. manihotis on cassava seeds (Persley 1979), and X. campestris pv. oryzae in rice (Thri Murty and Devadath 1984) have been studied. The reports show that these pathogens survived for 2 to 15 months in the seeds. We found that X. cucurbitae survived in pumpkin seeds for longer than 24 months. Thapa and Babadoost (2016) also reported that $X$. cucurbitae survived in pumpkin leaf and fruit tissues in the field for longer than 24 months. Our findings and the report by Thapa and Babadoost (2016) show that X. cucurbitae survives in pumpkin tissues for more than 24 months.

Ravanlou and Babadoost (2015) isolated X. cucurbitae from both seed surface and kernels inside the shell of pumpkin seeds. In our study, $X$. cucurbitae survived in both naturally infected and inoculated pumpkin seeds for more than 24 months. Although we did not investigate survival of $X$. cucurbitae in different parts of seeds, $X$. cucurbitae survives for more than 24 months with pumpkin seeds and remains pathogenic. Thus, effective seed treatments are needed to eradicate the pathogen carried on and/or in the seeds.

\section{Literature Cited}

Babadoost, M., and Ravanlou, A. 2012. Outbreak of bacterial spot (Xanthomonas cucurbitae) in pumpkin fields in Illinois. Plant Dis. 96:1222.

Babadoost, M., Ravanlou, A., Egel, D. S., and O'Brien, D. 2012. Occurrence of bacterial spot (Xanthomonas cucurbitae) in pumpkin fields in the Midwest. Phytopathology 102:S4.8.

Babadoost, M., and Zitter, T. A. 2009. Fruit rot of pumpkin: a serious threat to the pumpkin industry. Plant Dis. 93:772-782.

Barak, J. D., Koike, S. T., and Gilberston, R. L. 2001. The role of crop debris and weeds in the epidemiology of bacterial leaf spot of lettuce in California. Plant Dis. 85:169-178.

Bashan, Y., Diab, S., and Okon, Y. 1982. Survival of Xanthomonas campestris pv vesicatoria in pepper seeds and roots in symptomless and dry leaves in non-host plants and in the soil. Plant Soil 68:161-170.

Bineeta, S. B., Majumder, S., and Kumar, S. 1999. Fungal and bacterial diseases Pages 251-252 in: Diseases of Horticultural Crops Vegetable, Ornamentals and Mushrooms. L. R. Verma and R. C. Sharma, eds. Indus Publishing Co., New Delhi, India.

Bryan, M. K. 1930. Bacterial spot of squash. J. Agric. Res. 40:385-391.

Carisse, O., Ouimet, A., Toussaint, V., and Philion, V. 2000. Evaluation of the effect of seeds treatments, bactericides, and cultivars on bacterial leaf spot of lettuce caused by Xanthomonas campestris pv. vitians. Plant Dis. 84 . 295-299.

Egel, D. S., Foster, R., Maynard, E., Babadoost, M., Nair, A., Rivard, C., Kennelly, M., Hausbeck, M., Szendra, Z., Hutchison, W., Orshinsky, A., Eaton, T., Welty, C., and Miller, S. 2017. Midwest Vegetable Production Guide for Commercial Growers 2017. University of Illinois Extension C1373-17. https://www.plantgrower.org/uploads/6/5/5/4/65545169/01_mwvegguide_2017. pdf

Esgalhado, M. E., Roseiro, J. C., and Collaço, M. A. 1995. Interactive effects of pH and temperature on cell growth and polymer production by Xanthomonas campestris. Process Biochem. 30:667-671.

Kado, C. I. 2010. Plant Bacteriology. The American Phytopathological Society, St. Paul, MN.

Katagiri, F., Thilmony, R., and He, S. Y. 2002. The Arabidopsis thalianaPseudomonas syringae interaction. Arabidopsis Book 1:e0039.

Lamichhane, J. R., Varvaro, L., and Balestra, G. M. 2010. Bacterial leaf spot caused by Xanthomonas cucurbitae reported on pumpkin in Nepal. New Dis. Rep. 22:20.

Liu, Q., Ravanlou, A., and Babadoost, M. 2016. Occurrence of bacterial spot on pumpkin and squash fruit in the North Central Region of the United States and bacteria associated with the spots. Plant Dis. 100:2377-2382.

Persley, G. J. 1979. Studies on the survival and transmission of Xanthomonas manihotis on cassava seed. Ann. Appl. Biol. 93:159-166.

Pruvost, O., Robene-Soustrade, I., Ah-You, N., Jouen, E., Boyer, C., Waller, F., and Hostachy, B. 2008. First report of Xanthomonas cucurbitae causing bacterial leaf spot of pumpkin on Reunion Island. Plant Dis. 92:1591.

Pruvost, O., Robène-Soustrade, I., Ah-You, N., Jouen, E., Boyer, C., Wuster, G., Hostachy, B., Napoles, C., and Dogley, W. 2009. First report of Xanthomonas cucurbitae causing bacterial leaf spot of watermelon in the Seychelles. Plant Dis. 93:671.

Rademaker, J. L. W., Louws, F. J., Schultz, M. H., Rossbach, U., Vauterin, L., Swings, J., and de Bruijn, F. J. 2005. A comprehensive species to strain taxonomic framework for Xanthomonas. Phytopathology 95:1098-1111. 
Ravanlou, A., and Babadoost, M. 2015. Development of bacterial spot, incited by Xanthomonas cucurbitae, in pumpkin fields. HortScience 50:714-720.

Schaad, N. W., Jones, J. B., and Chun, W. 2001. Laboratory Guide for Identification of Plant Pathogenic Bacteria, 3rd Ed. American Phytopathological Society, St. Paul, MN.

Thapa, S., and Babadoost, M. 2016. Survival of Xanthomonas cucurbitae, cause of bacterial spot of cucurbits, in the field. Pages 153-156 in: Proceedings of Cucurbitaceae 2016 (11th Eucarpia Meeting on Genetics and Breeding of Cucurbitaceae), 24-28 July 2016, Warsaw, Poland.
Thri Murty, V. S., and Devadath, S. 1984. Role of seed in survival and transmission of Xanthomonas campestris pv. oryzae causing bacterial blight of rice. J. Phytopathol. 110:15-19.

Williams, P. H., and Zitter, T. A. 1996. Bacterial leaf spot. Page 35 in Compendium of Cucurbit Diseases. T. A. Zitter, D. L. Hopkins, and C. E. Thomas, eds. American Phytopathological Society, St. Paul, MN.

Zhao, Y. F., Damicone, J. P., and Blender, C. L. 2002. Detection, survival, and sources of bacterial inoculi for bacterial diseases of leafy crucifers in Oklahoma. Plant Dis. 86:883-888 